\title{
The Role and Regulation of Human Th17 Cells in Tumor Immunity
}

\author{
Jian Ye, Rob S. Livergood, and Guangyong Peng
}

From the Division of Infectious Diseases, Allergy \& Immunology, Department of Internal Medicine, Saint Louis University School of Medicine, St. Louis, Missouri

CME Accreditation Statement: This activity (“ASIP 2013 AJP CME Program in Pathogenesis") has been planned and implemented in accordance with the Essential Areas and policies of the Accreditation Council for Continuing Medical Education (ACCME) through the joint sponsorship of the American Society for Clinical Pathology (ASCP) and the American Society for Investigative Pathology (ASIP). ASCP is accredited by the ACCME to provide continuing medical education for physicians.

The ASCP designates this journal-based CME activity (“ASIP 2013 AJP CME Program in Pathogenesis”) for a maximum of 48 AMA PRA Category 1 Credit(s) ${ }^{\mathrm{TM}}$. Physicians should only claim credit commensurate with the extent of their participation in the activity.

CME Disclosures: The authors of this article and the planning committee members and staff have no relevant financial relationships with commercial interests to disclose.

Accepted for publication

August 9, 2012.

Address correspondence to Guangyong Peng, M.D., Ph.D., Division of Infectious Diseases, Allergy \& Immunology, Department of Internal Medicine, Saint Louis University School of Medicine, Doisy Research Center, Room 813, 1100 S. Grand Blvd., St. Louis, MO 63104. E-mail: gpeng@ slu.edu.

\begin{abstract}
T helper 17 (Th17) cells play critical roles in the pathogenesis of inflammatory and autoimmune diseases, as well as in host protection against pathogens. The contribution of Th17 cells to human tumor immunity, however, remains largely unknown. Since their identification in 2005, Th17 cells have been extensively studied in mouse tumor models and human cancer patients. Although accumulating data suggest the importance of Th17 cells to tumor immunity, conclusions regarding the functional role of Th17 cells remain controversial. In this review, we summarize current knowledge regarding the regulation and functional role of Th17 cells in human cancers. In particular, we emphasize several recently identified characteristics of Th17 cells, including plasticity, their relationship with regulatory $T$ cells, and Th17 cell heterogeneity in the tumor microenvironment. Improved understanding of these issues is critical to elucidating the role of Th17 cells in antitumor immunity and for the design of novel therapeutic approaches specifically targeting Th17 cells. (Am J Pathol 2013, 182: 10-20; http:// dx.doi.org/10.1016/j.ajpath.2012.08.041)
\end{abstract}

The identification in 2005 of T helper 17 (Th17) cells as a third subset of $\mathrm{T}$ helper cells changed the classical Th1/ Th2 paradigm of $\mathrm{T}$ helper cell differentiation. ${ }^{1,2}$ Compared with other T-cell lineages, Th17 cells are characterized by their production of IL-17, expression of unique transcription factors, and the performance of specific biological functions. ${ }^{3,4}$ Th17 cell differentiation and regulation have been extensively studied during the past 6 years. Differentiation of mouse Th17 cells is dependent on the specific cytokine combination of TGF- $\beta$ and IL- $6 .^{5-7}$ Furthermore, IL-6 induces IL-21 production, which synergizes with TGF- $\beta$ and IL-23 to promote the differentiation of Th17 cells in mice. ${ }^{8,9} \mathrm{IL}-1$ is required and important for the early differentiation of murine Th17 cells. ${ }^{10}$ IL-1 is a critical inducer for human Th17 cell differentiation, and the combination of IL-1, IL-6, and IL-23 is the optimal cytokine milieu for human Th17 generation. ${ }^{11}$ Molecular programming of transcription regulation is a determinant for Th17 development, in addition to cytokine regulation. At least six transcription factors are critical and required for Th17 cell development: signal transducer and activator of transcription 3 (Stat3), retinoid-related orphan receptor $\gamma \mathrm{t}(\mathrm{ROR}-\gamma \mathrm{t})$, nuclear receptor $\mathrm{ROR}-\alpha$, IFN regulatory factor 4 (IRF-4), B-cell-activating transcription factor (B-ATF), and hypoxia-inducible factor $1 \alpha$ $($ HIF $1-\alpha)$. $^{12-15}$

Th17 cells are important in host defense against microbial infections, including bacteria, mycobacteria, viruses, and

Supported in part by American Cancer Society grant RSG-10-160-01LIB (G.P.), the Melanoma Research Alliance (G.P.), and NIH grants AI097852 and AI094478 (G.P.). 
parasites. ${ }^{16,17}$ They also appear to be key mediators in the pathogenesis of a broad array of inflammatory and autoimmune diseases, including rheumatoid arthritis, psoriasis, and inflammatory bowel disease. ${ }^{17}$ Despite significant efforts by many research groups in this important area, the functional role of Th17 cells in tumor immunity remains unclear. Here, we review recently published articles that characterize Th17 cells in different types of human cancer. Specifically, we focus on the mechanisms for Th17 cell accumulation in tumor microenvironments, phenotypic features, regulation, and plasticity of tumor-infiltrating Th17 cells. We also discuss the potential role of Th17 cells in tumor immunity.

\section{Prevalence of Th17 Cells in Tumor Microenvironments}

Accumulating evidence suggests a close association of chronic infection and inflammation with tumorigenesis. Local inflammation in the tumor microenvironment recruits several different types of immune cells, including $\alpha \beta \mathrm{T}$ cells, $\gamma \delta \mathrm{T}$ cells, and natural killer (NK) T cells, all of which can play critical roles in tumor immunity. ${ }^{18,19}$ Given that Th17 cells have been identified as important players in the immunopathogenesis of inflammation, the presence of Th17 cells in a tumor microenvironment is expected. In fact, recent studies from our group and others have demonstrated that the development of Th17 cells in tumorinfiltrating lymphocytes is a general feature of cancers. Th17 cells have been found in many different types of human tumors, including lymphoma, ${ }^{20}$ myeloma, ${ }^{21,22}$ breast cancer, ${ }^{23,24}$ colon cancer, ${ }^{24-26}$ gastric cancer, ${ }^{27,28}$ hepatocellular cancer, ${ }^{25,29}$ melanoma, ${ }^{24,25,30}$ ovarian cancer, ${ }^{25,31-34}$ pancreatic cancer, ${ }^{25}$ and prostate cancer. ${ }^{35,36}$

\section{Phenotypic Features of Tumor-Infiltrating Th17 Cells}

\section{Cytokines}

In addition to IL-17, tumor-infiltrating Th17 cells also secrete other cytokines. Our group recently generated human Th17 clones from bulk tumor-infiltrating lymphocyte lines derived from melanoma, breast, and colon cancers. These tumor-derived Th17 clones secreted large amounts of IL- 8 and TNF- $\alpha$, small amounts of IL- 6 , but no IL-2, IL-4, IL-12, or IL-23, ${ }^{24}$ consistent with previous reports characterizing Th17 cells from other tissue sites. ${ }^{11,37}$ In addition, these tumor-infiltrating Th17 cells also secreted moderate amounts of IL-10 and TGF- $\beta 1,{ }^{24}$ suggesting that Th17 cells may perform regulatory functions in tumor microenvironments. ${ }^{38,39}$ However, studies from another group have shown that human ovarian cancerderived Th17 cells express high levels of IL-2, GMCSF, and IFN- $\gamma$, but negligible levels of IL- $10{ }^{25}$ These varied cytokine profiles of tumor-infiltrating Th17 cells further suggest the heterogeneity (IL- $17^{+} \mathrm{IFN}-\gamma^{+}$and IL$17^{+} \mathrm{IL}-10^{+}$) and polyfunction (effector or regulatory) of Th17 cells in tumor microenvironments. ${ }^{40,41}$ The differences may also reflect the fact that the various Th17 cells were obtained from patients with different types and/or different stages of cancer.

\section{Chemokine Receptors}

Th17 cells mediate inflammatory responses through selective migration and accumulative retention at specific sites. Recent studies have shown that the inflammatory microenvironment promotes production of CCL20, which preferentially recruits CC-chemokine receptor type 6 (CCR6)-expressing Th17 cells in human rheumatoid arthritis, psoriasis, and other chronic inflammatory diseases. ${ }^{42,43}$ In addition to universal expression of CCR6, Th17 cells can express Th1-associated (CCR2, CXCR3, CCR5, and CXCR6), Th2-associated (CCR4), and nonlymphoid tissue trafficking receptors (CCR4, CCR5, CCR6, CXCR3, and CXCR6), as well as homeostatic chemokine receptors (CD62L, CCR6, CCR7, CXCR4, and CXCR5) that are implicated in T-cell migration to and within lymphoid tissues. ${ }^{42}$ Our group analyzed chemokine receptor expression on tumor-infiltrating Th17 cells derived from melanoma, breast, and colon cancers. All of the Th17 clones expressed CCR2, CCR4, CCR5, CCR6, CCR7, and CXCR3, similar to the expression pattern in other types of $\mathrm{T}$ cells. ${ }^{24}$ These data suggest that tumor-infiltrating Th17 cells express homeostatic chemokine receptors as well as trafficking receptors, and also share major chemokine receptors with other T-cell lineages. Others, however, have reported that tumor-infiltrating Th17 cells express high levels of CXCR4 and CCR6, but not CCR2, CCR5, or CCR7 ${ }^{25}$ The difference between these studies may be due to different origins of Th17 cells from patients with different types of cancers.

\section{Other Markers}

Studies from our group demonstrated that tumor-derived Th17 clones uniformly express the memory T-cell phenotype $\mathrm{CCR}^{+} \mathrm{CD}^{2} \mathrm{~L}^{\mathrm{dim} /-}$ and $\mathrm{CD} 45 \mathrm{RA}^{-} \mathrm{CD} 45 \mathrm{RO}^{+} .{ }^{24,32}$ Moreover, tumor-derived Th17 cells had minimal or no expression of the cytotoxicity-associated markers CD56, granzyme $\mathrm{A}$ and $\mathrm{B}$, or Fas ligand, nor of the inhibitory molecule PD-1. ${ }^{24,25}$ Notably, tumor-infiltrating Th17 cells express some CTLA-4, CD25, and FOXP3, implying that tumor-infiltrating Th17 cells may have developmental plasticity and overlap phenotypically with T-regulatory cells (Tregs). ${ }^{24}$ Indeed, $\mathrm{IL}-17^{+} \mathrm{FOXP} 3{ }^{+} \mathrm{CD} 4{ }^{+}$populations have recently been observed in human colon and esophageal cancers. ${ }^{44,45}$ Furthermore, tumor-derived Th17 clones can significantly alter their phenotypes and can differentiate into $\mathrm{FOXP}^{+}$Tregs with potent suppressive function after in vitro repetitive T-cell receptor stimulation. ${ }^{46}$ 


\section{Potential Mechanisms Responsible for the Accumulation of Th17 Cells in Tumor Microenvironments}

Tumor Microenvironment Factors Mediate Recruitment and Expansion of Th17 Cells

Recent studies suggest several potential mechanisms responsible for the accumulation of Th17 cells in tumor sites. One suggested mechanism is that the tumor microenvironment preferentially recruits Th17 cells. Our group recently showed that tumor cells, as well as tumor-derived fibroblasts, secrete MCP-1 (the ligand for CCR2 or CCR4; alias CCL2) and RANTES (the ligand for CCR1, CCR3, or CCR5; alias CCL5), both of which strongly attract Th17 cell migration. ${ }^{24}$ These studies suggest that tumor microenvironments may use migratory mechanisms to selectively recruit Th17 cells from the periphery into tumor sites. Furthermore, human primary tumorinfiltrating Th17 cells isolated from melanoma, colon, hepatocellular, ovarian, pancreatic, and renal cell carcinomas express high levels of CXCR4 and CCR6, several CD49 integrins, and the C-type lectin receptor CD161 (alias KLRB1) ${ }^{25,47}$ In addition, high levels of CXCL12 (the ligand for CXCR4) and CCL20 (the ligand for CCR6) have been found in human tumor microenvironments, which could facilitate Th17 cell trafficking and migration into the tumor sites (Figure 1). ${ }^{47}$

Aside from the chemokine-mediated recruitment of Th17 cells into tumor sites, tumor microenvironment factors (tumor cells, as well as tumor-derived stromal cells such as fibroblasts and antigen-presenting cells) may also contribute to Th17 cell differentiation and expansion. ${ }^{24,32}$ Tumor cells and tumor environment stromal cells produce the proinflammatory cytokines IL- $1 \beta$, IL-6, IL-23, and TGF- $\beta$, which can form an optimal proinflammatory cytokine milieu suitable for human Th17 cell differentiation and expansion. $^{24,25,32}$ Blockade of IL-1 $\beta$, but not IL-6 or TGF $\beta$, decreases Th17 induction by human ovarian cancerassociated myeloid antigen-presenting cells, suggesting that IL-1 $\beta$ is crucial for Th17 cell generation in this tumor microenvironment. ${ }^{25,32}$ In addition to cytokines, other tumor microenvironment factors may also be critical for regulating Th17 cell differentiation and generation. One potential

\section{Tumor microenvironments}

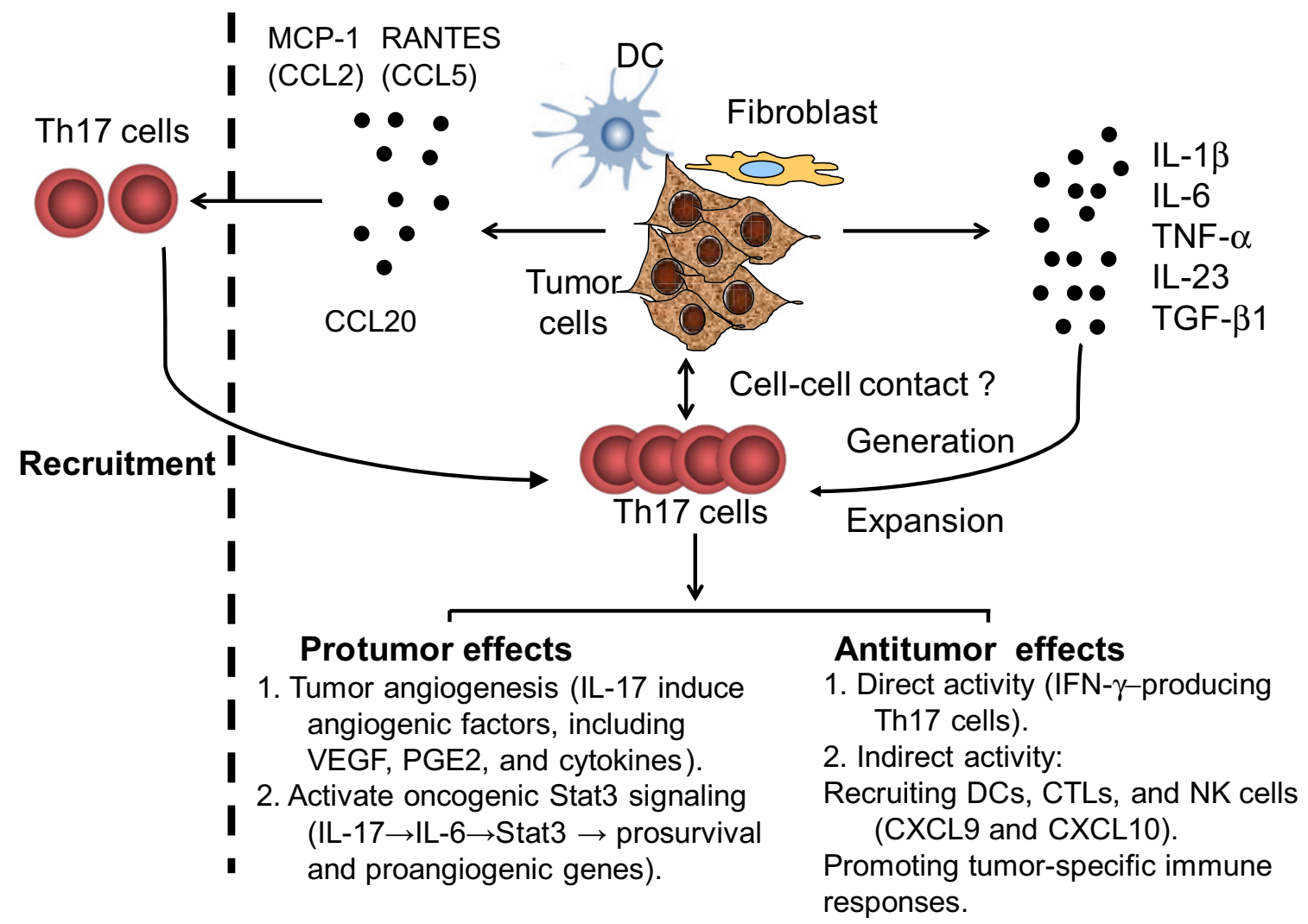

Figure 1 Recruitment, induction, expansion, and roles of Th17 cells in tumor microenvironments. Tumor microenvironmental chemokines including RANTES (CCL5), MCP-1 (CCL2), and CCL20 secreted by tumor cells and tumor-derived fibroblasts or dendritic cells mediate the recruitment of Th17 cells. Tumor cells, tumor-derived fibroblasts, and dendritic cells produce a proinflammatory cytokine milieu (IL-1 $\beta$, IL-6, TNF- $\alpha$, IL-23, and TGF- $\beta 1$ ) as well as provide cellcell contact engagements that facilitate the generation and expansion of Th17 cells. IL-17 secreted by Th17 cells may play protumor roles by promoting tumor angiogenesis through the induction of angiogenic factors, including VEGF, PGE2, and cytokines, and by activating oncogenic stat3 signaling (IL-17 $\rightarrow$ IL$6 \rightarrow$ Stat $3 \rightarrow$ prosurvival and proangiogenic genes). Th17 cells may also play antitumor roles. Th17 cells can directly eradicate tumor cells through production of IFN- $\gamma$, and Th17 cells can also indirectly enhance antitumor immunity through the recruitment of dendritic cells (DC), natural killer (NK) cells, and CD8 ${ }^{+}$ cytotoxic T lymphocytes (CTLS) into the tumor sites and promote specific antitumor immune responses. 
factor is retinoic acid, which enforces the generation of Tregs and inhibits the differentiation of Th17 cells. ${ }^{48}$ Aryl hydrocarbon receptor (AhR) ligand is another potential factor; AhR regulates Stat 1 activation and participates in the development of Th17 cells. ${ }^{49,50}$ In addition, hypoxiaderived metabolites in the tumor microenvironment, such as adenosine, may influence Th17 cell differentiation. ${ }^{51}$ Adenosine acts via $\mathrm{A}(2 \mathrm{~B})$ adenosine receptor [A(2B)AR] in dendritic cells to promote the development of Th17 cells. ${ }^{52}$ Notably, recent studies from our group suggest that tumor cells and tumor-derived fibroblasts play a great role in the expansion rather than the differentiation of human Th17 cells. ${ }^{24}$ Tumor cells and tumor environment stromal cells not only provide soluble cytokines, but also unknown cellcell contact signaling for the expansion of human Th17 cells, with the latter being more critical for Th17 cell regulation in the tumor microenvironment. ${ }^{24}$

\section{Inflammatory Tumor Microenvironments Promote Th17 Cell Attraction and Generation}

Chronic infection and inflammation are clearly important environmental factors for tumorigenesis. Infection-induced inflammation is triggered by interactions between pathogens and Toll-like receptors (TLRs) or other innate receptors expressed on immune and other cells. ${ }^{53}$ Recent studies have shown that activation of dendritic cells, monocytes, and peripheral blood mononuclear cells by TLR and nucleotidebinding oligomerization domain-containing protein (Nod) signaling can potentiate human Th17 cell differentiation and induction. ${ }^{54,55}$ TLR2 also plays an important role in regulating Th17 differentiation. Effects of TLR2 in CD4 ${ }^{+} \mathrm{T}$ lymphocytes can promote Th17-cell immune responses and regulate autoimmune disease pathogenesis. ${ }^{56}$ In addition, TLR2 stimulation can convert human naïve and effector Tregs into a Th17-like phenotype with reduced suppressive function. ${ }^{57}$ Recent findings from our group suggest that innate signaling may also influence the prevalence of Th17 cells in tumor microenvironments. In one study, TLR and Nod2 signaling increased MCP-1 and RANTES expression on tumor cells and tumor-derived fibroblasts, resulting in increased migration and trafficking of Th17 cells. ${ }^{24}$ In addition, TLR and Nod2 signaling accelerated the expansion of Th17 cells by promoting the secretion of inflammatory cytokines, including IL-1 $\beta$, IL-6, IL- 23 , and TGF- $\beta 1$, as well as by providing cell-contact engagement of tumor cells and tumor-derived fibroblasts. ${ }^{24}$ These results suggest that signaling mediated by local chronic inflammation and infections at tumor sites can directly influence tumor cells and tumor-derived stromal cells, which may also contribute to the accumulation of Th17 cells in tumor microenvironments.

\section{Role of Th17 Cells in Antitumor Immunity}

Although Th17 cells are prevalent within tumor microenvironments, their functional role in tumor immunity is controversial. Most studies investigating the relationship between Th17 cells and cancer have used mouse models, and results have been contradictory. Information regarding the role of human Th17 cells in cancer patients is limited (Table 1). A fundamental understanding of Th17 cells in antitumor immunity is critical to the development of novel cancer immunotherapeutic strategies (Figure 1).

\section{Protumor Effects}

Protumor activity mediated by IL-17 and Th17 has been observed both in mouse tumor models and in human cancer patients. The potential mechanisms responsible for the protumor activity of IL-17 or Th17 cells mainly involve angiogenesis and cytokine induction in the tumor microenvironment resulting in the promotion of tumor growth. IL-17 was shown to promote tumorigenicity of human cervical tumors in nude mice, which was associated with increased levels of IL-6 and IL-8 and with recruitment of macrophages at the tumor site. ${ }^{58}$ Furthermore, a study in a mouse model of colon adenocarcinoma demonstrated that the protumor effect of IL-17 was related to its capacity to induce tumor angiogenesis through the induction of a wide range of angiogenic factors, including VEGF, PGE2, keratinocyte-derived chemokine, and nitric oxide from fibroblasts and tumor cells. ${ }^{70}$ The same research group further showed that IL-17 increased net angiogenic activity and the growth of human non-small cell lung cancer by promoting CXCR2-dependent angiogenesis in vivo. ${ }^{59}$ In support of this notion, a recent study showed that accumulation of intratumoral IL-17-producing cells enhances human hepatocellular carcinoma progression by fostering angiogenesis. ${ }^{29}$ In addition to its involvement in angiogenesis, IL-17 can induce IL-6 production, which in turn activates the oncogenic signal Stat3, resulting in up-regulated prosurvival and proangiogenic genes. ${ }^{60}$

More recently, several clinical correlation studies in human cancer patients have demonstrated a protumor role of IL-17 or Th17 cells in different types of tumors. Hahn et $\mathrm{al}^{27}$ reported that a chronic increase in Th17 cell activity in the gut was associated with development of premalignant lesions of the gastroduodenal region. Tosolini et $\mathrm{al}^{26}$ analyzed 125 frozen colorectal tumor specimens and reported poor prognosis in patients with high Th17 cluster expression, whereas patients with high Th1 cluster expression had prolonged disease-free survival. A study by Wu et al ${ }^{61}$ suggested a role for Th 17 cells in the pathogenesis of acute myeloid leukemia. They observed that Th17 cell frequencies were significantly increased in peripheral blood samples from untreated patients with acute myeloid leukemia, compared with those from healthy volunteers. Moreover, increased IL-17 concentrations accompanied the increased Th17 cell frequencies in these patients. In multiple myeloma patients, elevated IL-17 produced by Th17 cells promoted myeloma cell growth and inhibited effector immune functions. ${ }^{62}$ Furthermore, in a study of ovarian cancer, chronic production of TNF- $\alpha$ in the tumor microenvironment increased myeloid cell recruitment in an IL-17-dependent manner that contributed to tumor-promoting actions. ${ }^{33}$ 
Table 1 Model Systems Used to Determine the Effects of Th17 or IL-17 in Tumor Immunity

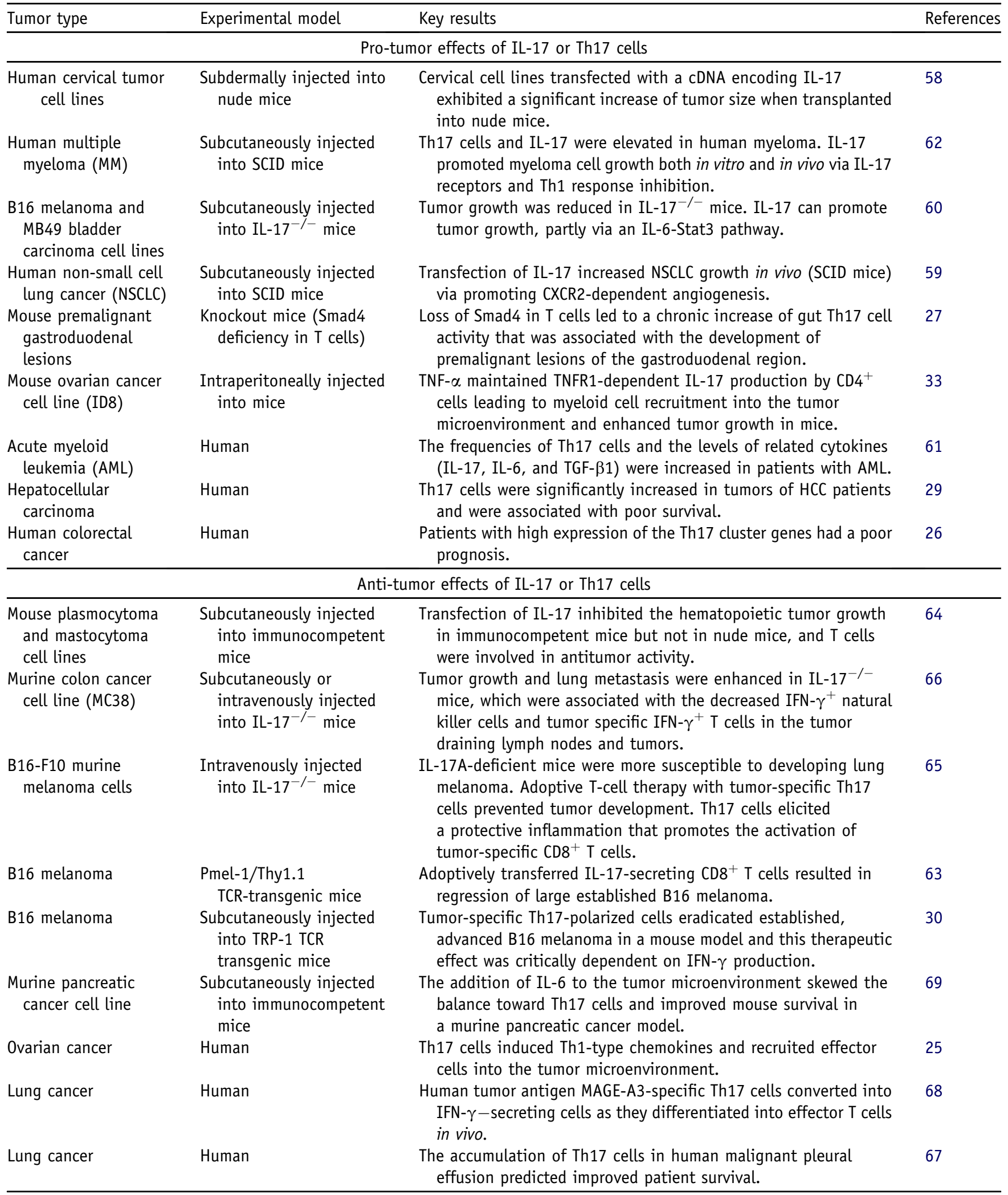

\section{Antitumor Effects}

Despite studies demonstrating a role for Th17 cells in promoting tumor growth, mounting evidence suggests that
Th17 cells may also have potent antitumor immune effects. Murine tumor models have shown that Th17 cells can directly eradicate tumor cells. Muranski et $\mathrm{al}^{30}$ demonstrated that tumor-specific Th17-polarized cells reduced established, 
advanced B16 melanoma in a mouse model, and that this therapeutic effect was critically dependent on IFN- $\gamma$ production. Furthermore, Hinrichs et $\mathrm{al}^{63}$ reported that adoptively transferred IL-17-secreting $\mathrm{CD} 8^{+} \mathrm{T}$ cells also enhanced antitumor immunity, resulting in regression of large established B16 melanoma. Transferred IL-17-producing $\mathrm{CD}^{+} \mathrm{T}$ cells converted into IFN- $\gamma$-producing effector $\mathrm{T}$ cells and mediated antitumor effects. These studies also suggest the plasticity of IL-17-producing $\mathrm{T}$ cells in the tumor microenvironment.

In addition to direct eradication of tumor cells, Th17 cells appear to have indirect antitumor effects by recruiting other tumor-specific immune cells and/or by promoting their antitumor immune responses. Benchetrit et $\mathrm{al}^{64}$ showed that transfection of IL-17 in immunocompetent mice but not in nude mice inhibited the hematopoietic tumor growth as a result of increased tumor-specific cytolytic $\mathrm{T}$ cells. Furthermore, an elegant study by Martin-Orozco et $\mathrm{al}^{65}$ provides strong evidence that Th17 plays an indirect antitumor role by promoting tumor-specific $\mathrm{CD} 8^{+} \mathrm{T}$-cell activation. They found that adoptive T-cell therapy with tumor-specific Th17 cells significantly recruited dendritic cells into the tumor site and draining lymph nodes, and also triggered a strong antitumor $\mathrm{CD} 8^{+} \mathrm{T}$-cell response. Kryczek et $\mathrm{al}^{66}$ showed that enhanced tumor growth and lung metastases in IL-17-deficient mice were associated with the decreased IFN- $\gamma^{+}$natural killer cells and tumor-specific IFN $-\gamma^{+} \mathrm{T}$ cells in tumor-draining lymph nodes and tumors. These three studies support the notion that the effects of IL-17 on tumor development are influenced by the existence of an adaptive immune system. In the presence of lymphocytes, IL-17 promotes tumor rejection; in their absence, IL-17 favors tumor growth and angiogenesis.

Most data supporting an antitumor role for Th17 cells are derived from murine models, and the role of human Th17 cells in antitumor immunity is incompletely defined. Kryczek et al ${ }^{25}$ investigated the functional role of Th17 cells and the associated mechanisms, as well as their clinical significance, in 201 ovarian cancer patients. They showed that Th17 cells can contribute to protective tumor immunity in humans by inducing the Th1-type chemokines CXCL9 and CXCL10, resulting in the recruitment of effector cells to the tumor microenvironment. Another group reported that the accumulation of Th17 cells in human malignant pleural effusions predicted improved patient survival. ${ }^{67}$ In addition, in lung cancer patients, human Th17 cells specific for the tumor antigen MAGE-A3 converted into IFN- $\gamma$ secreting cells during differentiation into effector T cells and mediated antitumor effects in vivo. ${ }^{68}$ Taken together, these data suggest the potential protective function of human Th17 cells in antitumor immunity.

\section{Plasticity and Balance of Th17 Cells and Tregs in Tumor Microenvironments}

Although different types of T-cell lineages have distinct gene expression and regulation signatures, each subset retains substantial developmental plasticity. Increasing evidence suggests that Th17 cells and Tregs have greater developmental plasticity than Th1 and Th2 subsets. ${ }^{71,72}$ Several studies have shown that human $\mathrm{CD}^{+}$Tregs can differentiate to IL-17producing cells $\left(\mathrm{IL}-17^{+} \mathrm{FOXP} 3^{+}\right.$), and that Th 17 cells can also express both FOXP3 and ROR- $\gamma \mathrm{t}\left(\mathrm{ROR}-\gamma \mathrm{t}^{+} \mathrm{FOXP}^{+}{ }^{+}\right)^{73,74}$ Furthermore, the differentiation of human Th17 cells preferentially occurs from naïve $\mathrm{FOXP}^{+}$Tregs rather than from conventional naïve $\mathrm{CD} 4{ }^{+}$T cells. $^{75}$ In addition to differentiation into Th17 cells, human memory Tregs themselves can secrete IL-17 ex vivo and constitutively express ROR- $\gamma$ t. These IL-17secreting memory Tregs share certain phenotypic and functional features with conventional Th17 cells. ${ }^{76}$

Recent studies suggest that epigenetic instability of cytokine and transcription factor gene loci may have a role in controlling the plasticity of Th17 cells. ${ }^{77}$ During the conversion of Tregs into Th17 cells, transcription factors such as Stat 3 and Stat 4 modulate the molecular process. Stat 3 downregulates FOXP3 expression, and Stat 3 , ROR- $\gamma$, and ROR$\alpha$ are required for IL-17 expression in Tregs. ${ }^{78}$ More recently, the transcription factor HIF1- $\alpha$ was also shown to direct Th17 cell and Treg development. ${ }^{15}$ Lack of HIF1- $\alpha$ diminished Th17 development, but it enhanced Treg differentiation and protected mice from autoimmune neuroinflammation. The mechanism involved is thought to involve an HIF1- $\alpha$ dependent glycolytic pathway that orchestrates a metabolic checkpoint for the differentiation of TH17 cells and Tregs. ${ }^{15}$

Th $17^{+} \mathrm{FOXP} 3^{+} \mathrm{T}$-cell populations have been observed in tumor environments. Kryczek et $\mathrm{al}^{44}$ reported that high levels of $\mathrm{IL}^{-1} 7^{+} \mathrm{FOXP} 3^{+} \mathrm{CD} 4^{+} \mathrm{T}$ cells selectively accumulated in the colitic microenvironment in association with colon carcinoma. $\mathrm{IL}-17^{+} \mathrm{FOXP} 3^{+} \mathrm{CD} 4^{+} \mathrm{T}$ cells functionally suppressed T-cell activation and stimulated inflammatory cytokine production in colitic tissues. ${ }^{44}$ Furthermore, another study showed that $\mathrm{CD} 4{ }^{+} \mathrm{IL}-17^{+} \mathrm{FOXP} 3^{+} \mathrm{T}$ cells exist in human esophageal cancer, ${ }^{45}$ and our group recently showed that tumor-infiltrating Th17 cells obtained from melanoma, breast, ovarian, and colon cancers also express FOXP3. ${ }^{24}$ Taken together, these studies provide clear evidence of the commitment and plasticity of Th17 cells and Tregs in various types of tumors. However, whether the IL$17^{+} \mathrm{FOXP} 3^{+}$T-cell population is derived from Tregs or Th17 cells is still unclear. In addition, whether Th17 cells can reciprocally convert into Tregs has not been fully described. In a study to address these important issues, our group demonstrated that Th17 clones generated from human tumor-infiltrating $\mathrm{T}$ lymphocytes can differentiate into $\mathrm{FOXP}^{+}$Tregs with potent suppressive function after in vitro repetitive T-cell receptor stimulation. ${ }^{46}$ This Th17to-Treg conversion involved the epigenetic modification of FOXP3 and reprogramming of gene expression profiles, including those of lineage-specific transcription factors and cytokine genes. These studies provide critical evidence that human tumor-infiltrating Th17 cells can differentiate into Tregs, and further demonstrate the potential for reciprocal plasticity between Th17 cells and Tregs. ${ }^{46}$ In addition to 


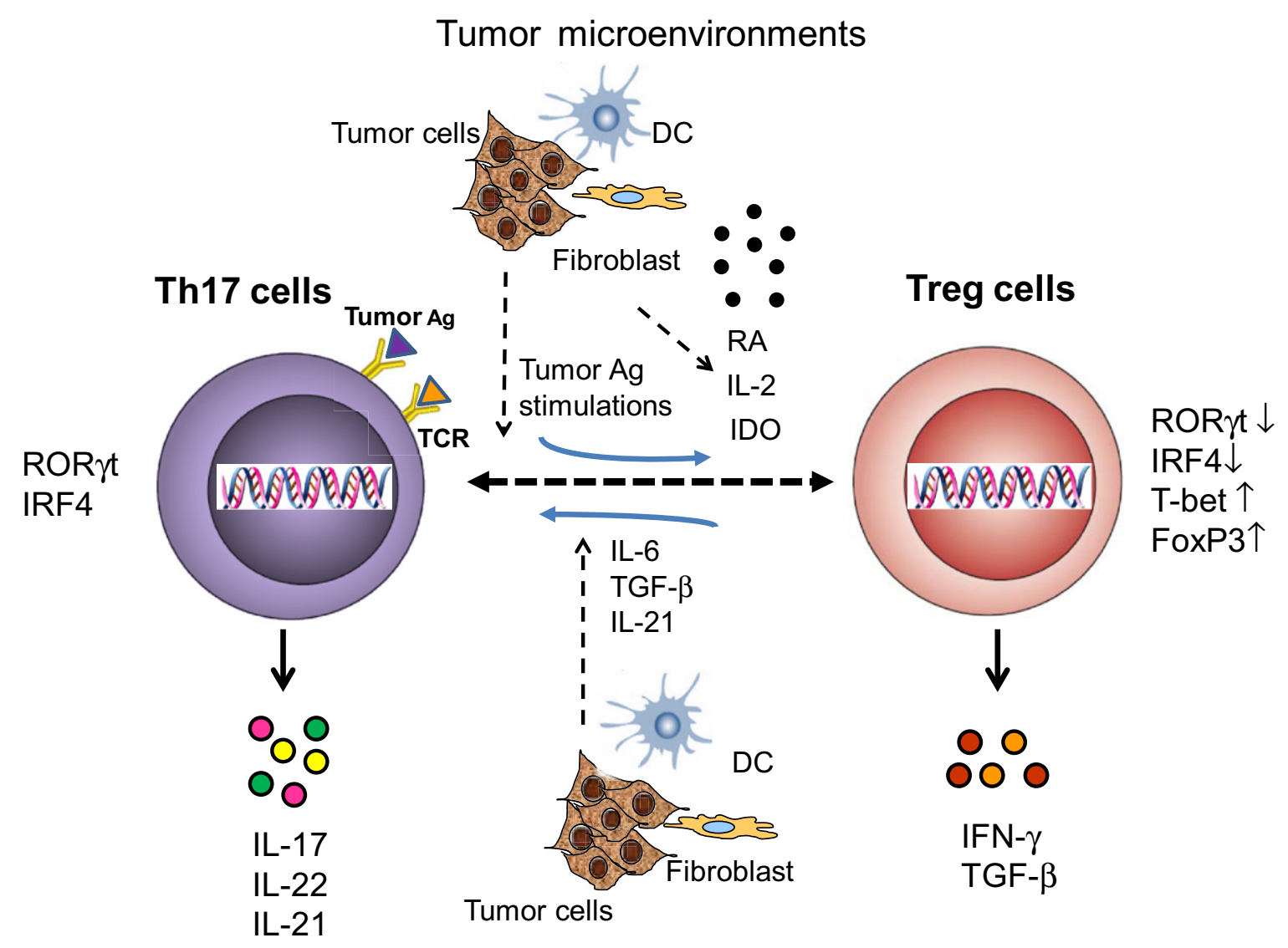

Figure 2 The plasticity and balance of Th17 and Tregs in tumor microenvironments. The balance and commitment between Th17 and Tregs may be controlled by the tumor microenvironment. In the presence of tumor microenvironmental cytokines IL- 6 , TGF- $\beta$, and IL- 21, CD $4^{+}$FOXP3 ${ }^{+}$Tregs can differentiate into IL-17-producing Th17 cells $\left(\mathrm{IL}-17^{+} / \mathrm{FOXP3}^{+}\right)$. Th17 cells also have the capacity to reciprocally differentiate into IFN- $\gamma^{+} \mathrm{FOXP} 3^{+}$Tregs by repetitive tumor antigen $(\mathrm{Ag})$ stimulations. In addition, tumor microenvironmental factors such as IL-2, retinoic acid (RA), or indoleamine 2,3-dioxygenase (ID0) may facilitate this Th17-to-Treg conversion.

potential antigenic stimulation, tumor-infiltrating myeloidderived suppressor cells may also contribute to the Th17-toTreg conversion, as well as to the plasticity of human Th17 cells and Tregs in tumor microenvironments. ${ }^{79}$ The mechanism of Th17 cell plasticity regulated by myeloidderived suppressor cells is dependent on myeloid-derived suppressor cell-derived TGF- $\beta$ and retinoic acid (Figure 2).

Given the significantly different roles and functions of Th17 cells and Tregs in human immunity, appropriate interactions and balance between them are critical for both physiological and pathological conditions. The potential for interconversion and balance between Th17 cells and Tregs has been strongly supported by recent studies in human tumor immunology. These studies indicate a dynamic interaction between Tregs and Th17 cells in tumor microenvironments, one in which Th17 cell and Treg cell numbers are reciprocally associated with tumor progression. ${ }^{28,31,44,47,66}$ In addition to reciprocal conversion of Tregs and Th17 cells, several additional tumor microenvironmental factors may contribute to the balance between these two subsets of cells. One major factor is the cytokine milieu of tumor microenvironment. Kryczek et $\mathrm{al}^{31}$ showed that IL-2 reduces Th17 cell differentiation in the tumor microenvironment, accompanied by an enhanced Treg compartment both in vitro and in vivo. Tregs can also promote Th17 development in vitro and in vivo through regulation of IL-2 ${ }^{80}$ Furthermore, Tregs have been shown to inhibit Th17 cell-mediated inflammation in an IL10-dependent manner. ${ }^{81,82}$ In addition to cytokine regulation, several other possible regulatory mechanisms have been proposed in nontumor-associated studies. Retinoic acid, a key regulator of TGF- $\beta$-dependent immune responses, can inhibit the IL-6-driven induction of proinflammatory Th17 cells by promoting anti-inflammatory Treg differentiation. ${ }^{48}$ Sharma et $\mathrm{al}^{83}$ showed that indoleamine 2,3-dioxygenase (IDO) functions as a molecular switch in tumor-draining lymph nodes, actively maintaining Tregs in their normal suppressive phenotype but allowing inflammation-induced conversion of Tregs to a polyfunctional T-helper phenotype similar to proinflammatory Th17 cells when blocked. Notably, retinoic acid and IDO are also critical suppressive mediators in tumor suppressive microenvironments. Whether these molecules are also involved in controlling the balance of Th17 cells and Tregs in the tumor microenvironment remains to be determined (Figure 2). A better understanding of the mechanisms 
and regulations induced by tumor microenvironments will, we trust, facilitate the development of novel strategies to manipulate Th17 cell and Treg commitment and functions for cancer immunotherapy.

\section{Conclusion and Future Perspectives}

The recent discovery of Th17 cells not only changes the classical Th1/Th2 paradigm of $\mathrm{T}$ helper cell differentiation, but also markedly alters conventional thinking regarding the role of $\mathrm{T}$ helper cells in antitumor immunity. Improved understanding of the nature and function of Th17 cells in tumor immunity should lead to opportunities for the development of novel therapeutic approaches for cancer patients. Current knowledge obtained from murine tumor models indicates that Th17 cells can exert both pro- and antitumor effects that depend on the tumor model used and the sources of IL-17 and Th17 cells, as well as on the specific cytokine and inflammatory conditions within the tumor microenvironment (Table 1). The functional contribution of human Th17 cells to tumor immunity remains controversial, and the data are derived mainly from limited clinical correlation studies of Th17 cells in cancer patients and disease progression. Mechanistic studies using knockout technology are urgently needed to firmly establish the role of Th17 cells in either promoting or inhibiting tumor growth and development. Furthermore, extensive investigation of Th17 cells from cancer patients with different types of tumors and different stages is critical for advancing knowledge regarding the role of Th17 cells in the immunopathogenesis of human cancers.

There are many additional challenging issues related to this specific research area. First, Th17 cells retain substantial developmental plasticity within the tumor microenvironment, and they can convert into other subsets of $\mathrm{T}$ cells, including Th1 cells and Tregs. Future studies will need to focus on defining the molecular mechanisms and identifying the tumor microenvironment factors responsible for $\mathrm{T}$-cell lineage commitment, plasticity, and reciprocity of Th1 cells, Th17 cells, and Tregs. Such information would be critical to development of strategies using Th17 and/or Th1 cells as potential therapeutic effector cells in cancer patients. Second, increasing evidence suggests a dynamic interaction and reciprocal conversion between Tregs and Th17 cells in tumor microenvironments, and the numbers of Th17 cells and Tregs appear to be reciprocally associated with tumor progression. $^{28,31,44,47,66}$ Identification of the molecular mechanisms that regulate Th17 cell and Treg interconversion and balance in the tumor microenvironment could also lead to novel target therapeutic strategies for cancer and other human diseases. Another important issue is the potential heterogeneity of Th17 cell subsets in the tumor microenvironment. Different types of Th17 cells, including IL- $17^{+} \mathrm{IFN}-\gamma^{+}$and $\mathrm{IL}-17^{+} \mathrm{IL}-10^{+}$Th17 cells, have been documented in autoimmune and inflammatory diseases. ${ }^{38-41}$
Clearly, these two types of Th17 cells have been observed in tumor-infiltrating lymphocytes; however, whether the generation of these two types of Th17 cells is due to variations in cellular circumstances, disease stage, or type of tumor is still unknown. Furthermore, the precursor origin or origins of these two types of Th17 cells, as well as their specific roles in antitumor immunity, inflammation, or regulatory effects, are as yet undefined. Characterization of the molecular signatures and functional roles of Th17 cells, as well as identification of the mechanisms underlying Th17 cell heterogeneity in individual tumors or during tumor development, is also urgently required for the development of effective and specific antitumor immunotherapies.

\section{Acknowledgments}

We acknowledge the contributions of the many researchers whose work could not be cited in this review because of space limitations.

\section{References}

1. Harrington LE, Hatton RD, Mangan PR, Turner H, Murphy TL, Murphy KM, Weaver CT: Interleukin 17-producing CD4+ effector T cells develop via a lineage distinct from the $\mathrm{T}$ helper type 1 and 2 lineages. Nat Immunol 2005, 6:1123-1132

2. Park H, Li Z, Yang XO, Chang SH, Nurieva R, Wang YH, Wang Y, Hood L, Zhu Z, Tian Q, Dong C: A distinct lineage of CD4 T cells regulates tissue inflammation by producing interleukin 17 . Nat Immunol 2005, 6:1133-1141

3. Dong C: TH17 cells in development: an updated view of their molecular identity and genetic programming. Nat Rev Immunol 2008, 8:337-348

4. Bettelli E, Korn T, Kuchroo VK: Th17: the third member of the effector T cell trilogy. Curr Opin Immunol 2007, 19:652-657

5. Veldhoen M, Hocking RJ, Atkins CJ, Locksley RM, Stockinger B: TGFbeta in the context of an inflammatory cytokine milieu supports de novo differentiation of IL-17-producing T cells. Immunity 2006, 24: 179-189

6. Bettelli E, Carrier Y, Gao W, Korn T, Strom TB, Oukka M, Weiner HL, Kuchroo VK: Reciprocal developmental pathways for the generation of pathogenic effector TH17 and regulatory T cells. Nature 2006, 441:235-238

7. Mangan PR, Harrington LE, O'Quinn DB, Helms WS, Bullard DC, Elson CO, Hatton RD, Wahl SM, Schoeb TR, Weaver CT: Transforming growth factor-beta induces development of the $T(H) 17$ lineage. Nature 2006, 441:231-234

8. Korn T, Bettelli E, Gao W, Awasthi A, Jäger A, Strom TB, Oukka M, Kuchroo VK: IL-21 initiates an alternative pathway to induce proinflammatory $\mathrm{T}(\mathrm{H}) 17$ cells. Nature 2007, 448:484-487

9. Zhou L, Ivanov II, Spolski R, Min R, Shenderov K, Egawa T, Levy DE, Leonard WJ, Littman DR: IL-6 programs $\mathrm{T}(\mathrm{H})-17$ cell differentiation by promoting sequential engagement of the IL-21 and IL-23 pathways. Nat Immunol 2007, 8:967-974

10. Chung Y, Chang SH, Martinez GJ, Yang XO, Nurieva R, Kang HS, Ma L, Watowich SS, Jetten AM, Tian Q, Dong C: Critical regulation of early Th17 cell differentiation by interleukin-1 signaling. Immunity 2009, 30:576-587

11. Wilson NJ, Boniface K, Chan JR, McKenzie BS, Blumenschein WM, Mattson JD, Basham B, Smith K, Chen T, Morel F, Lecron JC, Kastelein RA, Cua DJ, McClanahan TK, Bowman EP, de Waal Malefyt R: Development, cytokine profile and function of human 
interleukin 17-producing helper $\mathrm{T}$ cells. Nat Immunol 2007, 8: 950-957

12. Ivanov II, McKenzie BS, Zhou L, Tadokoro CE, Lepelley A, Lafaille JJ, Cua DJ, Littman DR: The orphan nuclear receptor RORgammat directs the differentiation program of proinflammatory IL-17+ T helper cells. Cell 2006, 126:1121-1133

13. Chen Q, Yang W, Gupta S, Biswas P, Smith P, Bhagat G, Pernis AB: IRF-4-binding protein inhibits interleukin-17 and interleukin-21 production by controlling the activity of IRF-4 transcription factor. Immunity 2008, 29:899-911

14. Dang EV, Barbi J, Yang HY, Jinasena D, Yu H, Zheng Y, Bordman Z, Fu J, Kim Y, Yen HR, Luo W, Zeller K, Shimoda L, Topalian SL, Semenza GL, Dang CV, Pardoll DM, Pan F: Control of T(H)17/T(reg) balance by hypoxia-inducible factor 1 . Cell 2011, 146:772-784

15. Shi LZ, Wang R, Huang G, Vogel P, Neale G, Green DR, Chi H: HIF1alpha-dependent glycolytic pathway orchestrates a metabolic checkpoint for the differentiation of TH17 and Treg cells. J Exp Med 2011, 208:1367-1376

16. Dandekar S, George MD, Baumler AJ: Th17 cells, HIV and the gut mucosal barrier. Curr Opin HIV AIDS 2010, 5:173-178

17. Tesmer LA, Lundy SK, Sarkar S, Fox DA: Th17 cells in human disease. Immunol Rev 2008, 223:87-113

18. Koebel CM, Vermi W, Swann JB, Zerafa N, Rodig SJ, Old LJ, Smyth MJ, Schreiber RD: Adaptive immunity maintains occult cancer in an equilibrium state. Nature 2007, 450:903-907

19. Dunn GP, Old LJ, Schreiber RD: The immunobiology of cancer immunosurveillance and immunoediting. Immunity 2004, 21:137-148

20. Galand C, Donnou S, Crozet L, Brunet S, Touitou V, Ouakrim H, Fridman WH, Sautès-Fridman C, Fisson S: Th17 cells are involved in the local control of tumor progression in primary intraocular lymphoma. PLoS One 2011, 6:e24622

21. Dhodapkar KM, Barbuto S, Matthews P, Kukreja A, Mazumder A, Vesole D, Jagannath S, Dhodapkar MV: Dendritic cells mediate the induction of polyfunctional human IL17-producing cells (Th17-1 cells) enriched in the bone marrow of patients with myeloma. Blood 2008, 112:2878-2885

22. Noonan K, Marchionni L, Anderson J, Pardoll D, Roodman GD, Borrello I: A novel role of IL-17-producing lymphocytes in mediating lytic bone disease in multiple myeloma. Blood 2010, 116: $3554-3563$

23. Zhu X, Mulcahy LA, Mohammed RA, Lee AH, Franks HA, Kilpatrick L, Yilmazer A, Paish EC, Ellis IO, Patel PM, Jackson AM: IL-17 expression by breast-cancer-associated macrophages: IL-17 promotes invasiveness of breast cancer cell lines. Breast Cancer Res 2008, 10:R95

24. Su X, Ye J, Hsueh EC, Zhang Y, Hoft DF, Peng G: Tumor microenvironments direct the recruitment and expansion of human Th17 cells. J Immunol 2010, 184:1630-1641

25. Kryczek I, Banerjee M, Cheng P, Vatan L, Szeliga W, Wei S, Huang E, Finlayson E, Simeone D, Welling TH, Chang A, Coukos G, Liu R, Zou W: Phenotype, distribution, generation, and functional and clinical relevance of Th17 cells in the human tumor environments. Blood 2009, 114:1141-1149

26. Tosolini M, Kirilovsky A, Mlecnik B, Fredriksen T, Mauger S, Bindea G, Berger A, Bruneval P, Fridman WH, Pagès F, Galon J: Clinical impact of different classes of infiltrating $\mathrm{T}$ cytotoxic and helper cells (Th1, th2, treg, th17) in patients with colorectal cancer [Erratum appeared in Cancer Res 2011, 71:4732]. Cancer Res 2011, $71: 1263-1271$

27. Hahn JN, Falck VG, Jirik FR: Smad4 deficiency in T cells leads to the Th17-associated development of premalignant gastroduodenal lesions in mice. J Clin Invest 2011, 121:4030-4042

28. Maruyama T, Kono K, Mizukami Y, Kawaguchi Y, Mimura K, Watanabe M, Izawa S, Fujii H: Distribution of Th17 cells and FoxP3(+) regulatory $\mathrm{T}$ cells in tumor-infiltrating lymphocytes, tumordraining lymph nodes and peripheral blood lymphocytes in patients with gastric cancer. Cancer Sci 2010, 101:1947-1954
29. Zhang JP, Yan J, Xu J, Pang XH, Chen MS, Li L, Wu C, Li SP, Zheng L: Increased intratumoral IL-17-producing cells correlate with poor survival in hepatocellular carcinoma patients. J Hepatol 2009, 50: 980-989

30. Muranski P, Boni A, Antony PA, Cassard L, Irvine KR, Kaiser A, Paulos CM, Palmer DC, Touloukian CE, Ptak K, Gattinoni L, Wrzesinski C, Hinrichs CS, Kerstann KW, Feigenbaum L, Chan CC, Restifo NP: Tumor-specific Th17-polarized cells eradicate large established melanoma. Blood 2008, 112:362-373

31. Kryczek I, Wei S, Zou L, Altuwaijri S, Szeliga W, Kolls J, Chang A, Zou W: Cutting edge: th17 and regulatory $\mathrm{T}$ cell dynamics and the regulation by IL-2 in the tumor microenvironment. J Immunol 2007, 178:6730-6733

32. Miyahara Y, Odunsi K, Chen W, Peng G, Matsuzaki J, Wang RF: Generation and regulation of human CD4+ IL-17-producing T cells in ovarian cancer. Proc Natl Acad Sci USA 2008, 105:15505-15510

33. Charles KA, Kulbe H, Soper R, Escorcio-Correia M, Lawrence T, Schultheis A, Chakravarty P, Thompson RG, Kollias G, Smyth JF, Balkwill FR, Hagemann T: The tumor-promoting actions of TNFalpha involve TNFR1 and IL-17 in ovarian cancer in mice and humans. J Clin Invest 2009, 119:3011-3023

34. Leveque L, Deknuydt F, Bioley G, Old LJ, Matsuzaki J, Odunsi K, Ayyoub M, Valmori D: Interleukin 2-mediated conversion of ovarian cancer-associated $\mathrm{CD} 4+$ regulatory $\mathrm{T}$ cells into proinflammatory interleukin 17-producing helper T cells. J Immunother 2009, 32: 101-108

35. Sfanos KS, Bruno TC, Maris CH, Xu L, Thoburn CJ, DeMarzo AM, Meeker AK, Isaacs WB, Drake CG: Phenotypic analysis of prostateinfiltrating lymphocytes reveals TH17 and Treg skewing. Clin Cancer Res 2008, 14:3254-3261

36. Derhovanessian E, Adams V, Hähnel K, Groeger A, Pandha H, Ward S, Pawelec G: Pretreatment frequency of circulating IL-17+ CD4+ T-cells, but not Tregs, correlates with clinical response to whole-cell vaccination in prostate cancer patients. Int J Cancer 2009, 125:1372-1379

37. Annunziato F, Cosmi L, Santarlasci V, Maggi L, Liotta F, Mazzinghi B, Parente E, Fili L, Ferri S, Frosali F, Giudici F, Romagnani P, Parronchi P, Tonelli F, Maggi E, Romagnani S: Phenotypic and functional features of human Th17 cells. J Exp Med 2007, 204:1849-1861

38. McGeachy MJ, Bak-Jensen KS, Chen Y, Tato CM, Blumenschein W, McClanahan T, Cua DJ: TGF-beta and IL-6 drive the production of IL17 and IL-10 by $\mathrm{T}$ cells and restrain $\mathrm{T}(\mathrm{H})-17$ cell-mediated pathology. Nat Immunol 2007, 8:1390-1397

39. McGeachy MJ, Cua DJ: Th17 cell differentiation: the long and winding road. Immunity 2008, 28:445-453

40. Peters A, Lee Y, Kuchroo VK: The many faces of Th17 cells. Curr Opin Immunol 2011, 23:702-706

41. Ghoreschi K, Laurence A, Yang XP, Hirahara K, O’Shea JJ: T helper 17 cell heterogeneity and pathogenicity in autoimmune disease. Trends Immunol 2011, 32:395-401

42. Lim HW, Lee J, Hillsamer P, Kim CH: Human Th17 cells share major trafficking receptors with both polarized effector $\mathrm{T}$ cells and FOXP3+ regulatory T cells. J Immunol 2008, 180:122-129

43. Hirota $\mathrm{K}$, Yoshitomi $\mathrm{H}$, Hashimoto $\mathrm{M}$, Maeda $\mathrm{S}$, Teradaira $\mathrm{S}$, Sugimoto N, Yamaguchi T, Nomura T, Ito H, Nakamura $T$, Sakaguchi N, Sakaguchi S: Preferential recruitment of CCR6expressing Th17 cells to inflamed joints via CCL20 in rheumatoid arthritis and its animal model. J Exp Med 2007, 204:2803-2812

44. Kryczek I, Wu K, Zhao E, Wei S, Vatan L, Szeliga W, Huang E, Greenson J, Chang A, Rolinski J, Radwan P, Fang J, Wang G, Zou W: $\mathrm{IL}-17+$ regulatory $\mathrm{T}$ cells in the microenvironments of chronic inflammation and cancer. J Immunol 2011, 186:4388-4395

45. Huang C, Fu ZX: Localization of IL-17+Foxp3+ T cells in esophageal cancer. Immunol Invest 2011, 40:400-412

46. Ye J, Su X, Hsueh EC, Zhang Y, Koenig JM, Hoft DF, Peng G: Human tumor-infiltrating Th17 cells have the capacity to differentiate 
into IFN-gamma(+) and FOXP3(+) T cells with potent suppressive function. Eur J Immunol 2011, 41:936-951

47. Zou W, Restifo NP: $\mathrm{T}(\mathrm{H}) 17$ cells in tumour immunity and immunotherapy [Erratum appeared in Nat Rev Immunol 2011, 11:565]. Nat Rev Immunol 2010, 10:248-256

48. Mucida D, Park Y, Kim G, Turovskaya O, Scott I, Kronenberg M, Cheroutre H: Reciprocal TH17 and regulatory T cell differentiation mediated by retinoic acid. Science 2007, 317:256-260

49. Kimura A, Naka T, Nohara K, Fujii-Kuriyama Y, Kishimoto T: Aryl hydrocarbon receptor regulates Stat1 activation and participates in the development of Th17 cells. Proc Natl Acad Sci USA 2008, 105: 9721-9726

50. Veldhoen M, Hirota K, Westendorf AM, Buer J, Dumoutier L, Renauld JC, Stockinger B: The aryl hydrocarbon receptor links TH17-cell-mediated autoimmunity to environmental toxins. Nature 2008, 453:106-109

51. Ohta A, Gorelik E, Prasad SJ, Ronchese F, Lukashev D, Wong MK, Huang X, Caldwell S, Liu K, Smith P, Chen JF, Jackson EK, Apasov S, Abrams S, Sitkovsky M: A2A adenosine receptor protects tumors from antitumor $\mathrm{T}$ cells. Proc Natl Acad Sci USA 2006, 103: 13132-13137

52. Wilson JM, Kurtz CC, Black SG, Ross WG, Alam MS, Linden J, Ernst PB: The A2B adenosine receptor promotes Th17 differentiation via stimulation of dendritic cell IL-6. J Immunol 2011, 186:6746-6752

53. Medzhitov R: Toll-like receptors and innate immunity. Nat Rev Immunol 2001, 1:135-145

54. van Beelen AJ, Zelinkova Z, Taanman-Kueter EW, Muller FJ, Hommes DW, Zaat SA, Kapsenberg ML, de Jong EC: Stimulation of the intracellular bacterial sensor NOD2 programs dendritic cells to promote interleukin-17 production in human memory T cells. Immunity 2007, 27:660-669

55. Evans HG, Suddason T, Jackson I, Taams LS, Lord GM: Optimal induction of $\mathrm{T}$ helper 17 cells in humans requires $\mathrm{T}$ cell receptor ligation in the context of Toll-like receptor-activated monocytes. Proc Natl Acad Sci USA 2007, 104:17034-17039

56. Reynolds JM, Pappu BP, Peng J, Martinez GJ, Zhang Y, Chung Y, Ma L, Yang XO, Nurieva RI, Tian Q, Dong C: Toll-like receptor 2 signaling in $\mathrm{CD} 4(+) \mathrm{T}$ lymphocytes promotes $\mathrm{T}$ helper 17 responses and regulates the pathogenesis of autoimmune disease. Immunity 2010, 32:692-702

57. Nyirenda MH, Sanvito L, Darlington PJ, O'Brien K, Zhang GX, Constantinescu CS, Bar-Or A, Gran B: TLR2 stimulation drives human naive and effector regulatory $\mathrm{T}$ cells into a Th17-like phenotype with reduced suppressive function. J Immunol 2011, 187:2278-2290

58. Tartour E, Fossiez F, Joyeux I, Galinha A, Gey A, Claret E, SastreGarau X, Couturier J, Mosseri V, Vives V, Banchereau J, Fridman WH, Wijdenes J, Lebecque S, Sautès-Fridman C: Interleukin 17, a T-cell-derived cytokine, promotes tumorigenicity of human cervical tumors in nude mice. Cancer Res 1999, 59:3698-3704

59. Numasaki M, Watanabe M, Suzuki T, Takahashi H, Nakamura A, McAllister F, Hishinuma T, Goto J, Lotze MT, Kolls JK, Sasaki H: IL17 enhances the net angiogenic activity and in vivo growth of human non-small cell lung cancer in SCID mice through promoting CXCR-2dependent angiogenesis. J Immunol 2005, 175:6177-6189

60. Wang L, Yi T, Kortylewski M, Pardoll DM, Zeng D, Yu H: IL-17 can promote tumor growth through an IL-6-Stat3 signaling pathway. J Exp Med 2009, 206:1457-1464

61. Wu C, Wang S, Wang F, Chen Q, Peng S, Zhang Y, Qian J, Jin J, $\mathrm{Xu} \mathrm{H}$ : Increased frequencies of T helper type 17 cells in the peripheral blood of patients with acute myeloid leukaemia. Clin Exp Immunol 2009, 158:199-204

62. Prabhala RH, Pelluru D, Fulciniti M, Prabhala HK, Nanjappa P, Song W, Pai C, Amin S, Tai YT, Richardson PG, Ghobrial IM, Treon SP, Daley JF, Anderson KC, Kutok JL, Munshi NC: Elevated IL-17 produced by TH17 cells promotes myeloma cell growth and inhibits immune function in multiple myeloma. Blood 2010, 115: $5385-5392$
63. Hinrichs CS, Kaiser A, Paulos CM, Cassard L, Sanchez-Perez L, Heemskerk B, Wrzesinski C, Borman ZA, Muranski P, Restifo NP: Type $17 \mathrm{CD} 8+\mathrm{T}$ cells display enhanced antitumor immunity. Blood 2009, 114:596-599

64. Benchetrit F, Ciree A, Vives V, Warnier G, Gey A, Sautès-Fridman C, Fossiez F, Haicheur N, Fridman WH, Tartour E: Interleukin-17 inhibits tumor cell growth by means of a T-cell-dependent mechanism. Blood 2002, 99:2114-2121

65. Martin-Orozco N, Muranski P, Chung Y, Yang XO, Yamazaki T, Lu S, Hwu P, Restifo NP, Overwijk WW, Dong C: T helper 17 cells promote cytotoxic $\mathrm{T}$ cell activation in tumor immunity. Immunity 2009, 31:787-798

66. Kryczek I, Wei S, Szeliga W, Vatan L, Zou W: Endogenous IL-17 contributes to reduced tumor growth and metastasis. Blood 2009, 114:357-359

67. Ye ZJ, Zhou Q, Gu YY, Qin SM, Ma WL, Xin JB, Tao XN, Shi HZ: Generation and differentiation of IL-17-producing CD4+ T cells in malignant pleural effusion. J Immunol 2010, 185:6348-6354

68. Hamaï A, Pignon P, Raimbaud I, Duperrier-Amouriaux K, Senellart H, Hiret S, Douillard JY, Bennouna J, Ayyoub M, Valmori D: Human $\mathrm{T}(\mathrm{H}) 17$ immune cells specific for the tumor antigen MAGE-A3 convert to IFN-gamma-secreting cells as they differentiate into effector T cells in vivo. Cancer Res 2012, 72:1059-1063

69. Gnerlich JL, Mitchem JB, Weir JS, Sankpal NV, Kashiwagi H, Belt BA, Porembka MR, Herndon JM, Eberlein TJ, Goedegebuure P, Linehan DC: Induction of Th17 cells in the tumor microenvironment improves survival in a murine model of pancreatic cancer. J Immunol 2010, 185:4063-4071

70. Numasaki M, Fukushi J, Ono M, Narula SK, Zavodny PJ, Kudo T, Robbins PD, Tahara H, Lotze MT: Interleukin-17 promotes angiogenesis and tumor growth. Blood 2003, 101:2620-2627

71. Zhou L, Chong MM, Littman DR: Plasticity of CD4+ T cell lineage differentiation. Immunity 2009, 30:646-655

72. Lee YK, Mukasa R, Hatton RD, Weaver CT: Developmental plasticity of Th17 and Treg cells. Curr Opin Immunol 2009, 21:274-280

73. Koenen HJ, Smeets RL, Vink PM, van Rijssen E, Boots AM, Joosten I: Human CD25highFoxp3pos regulatory T cells differentiate into IL-17-producing cells. Blood 2008, 112:2340-2352

74. Voo KS, Wang YH, Santori FR, Boggiano C, Arima K, Bover L, Hanabuchi S, Khalili J, Marinova E, Zheng B, Littman DR, Liu YJ: Identification of IL-17-producing FOXP3 + regulatory $\mathrm{T}$ cells in humans. Proc Natl Acad Sci USA 2009, 106:4793-4798

75. Valmori D, Raffin C, Raimbaud I, Ayyoub M: Human RORgammat+ TH17 cells preferentially differentiate from naive FOXP3+Treg in the presence of lineage-specific polarizing factors. Proc Natl Acad Sci USA 2010, 107:19402-19407

76. Ayyoub M, Deknuydt F, Raimbaud I, Dousset C, Leveque L, Bioley G, Valmori D: Human memory FOXP3+ Tregs secrete IL-17 ex vivo and constitutively express the $\mathrm{T}(\mathrm{H}) 17$ lineage-specific transcription factor RORgamma t. Proc Natl Acad Sci USA 2009, 106: $8635-8640$

77. Mukasa R, Balasubramani A, Lee YK, Whitley SK, Weaver BT, Shibata Y, Crawford GE, Hatton RD, Weaver CT: Epigenetic instability of cytokine and transcription factor gene loci underlies plasticity of the T helper 17 cell lineage. Immunity 2010, 32:616-627

78. Chaudhry A, Rudra D, Treuting P, Samstein RM, Liang Y, Kas A, Rudensky AY: CD4+ regulatory T cells control TH17 responses in a Stat3-dependent manner. Science 2009, 326:986-991

79. Hoechst B, Gamrekelashvili J, Manns MP, Greten TF, Korangy F: Plasticity of human Th17 cells and iTregs is orchestrated by different subsets of myeloid cells. Blood 2011, 117:6532-6541

80. Chen Y, Haines CJ, Gutcher I, Hochweller K, Blumenschein WM, McClanahan T, Hämmerling G, Li MO, Cua DJ, McGeachy MJ: Foxp3(+) regulatory $\mathrm{T}$ cells promote $\mathrm{T}$ helper 17 cell development in vivo through regulation of interleukin-2. Immunity 2011, 34:409-421

81. Huber S, Gagliani N, Esplugues E, O'Connor W Jr, Huber FJ, Chaudhry A, Kamanaka M, Kobayashi Y, Booth CJ, Rudensky AY, 
Roncarolo MG, Battaglia M, Flavell RA: Th17 cells express interleukin-10 receptor and are controlled by Foxp3- and Foxp3+ regulatory $\mathrm{CD} 4+\mathrm{T}$ cells in an interleukin-10-dependent manner. Immunity 2011, 34:554-565

82. Chaudhry A, Samstein RM, Treuting P, Liang Y, Pils MC, Heinrich JM, Jack RS, Wunderlich FT, Brüning JC, Müller W, Rudensky AY:
Interleukin-10 signaling in regulatory $\mathrm{T}$ cells is required for suppression of Th17 cell-mediated inflammation. Immunity 2011, 34:566-578

83. Sharma MD, Hou DY, Liu Y, Koni PA, Metz R, Chandler P, Mellor AL, He Y, Munn DH: Indoleamine 2,3-dioxygenase controls conversion of Foxp3+ Tregs to TH17-like cells in tumor-draining lymph nodes. Blood 2009, 113:6102-6111 